\title{
Depreciation of the Economic Value of Historic Properties
}

\author{
Svetlana Albu, Ion Albu \\ Engineering, Law and Real Estate Valuation, Technical University of Moldova, Chisinau, Republic of Moldova \\ Email: svetlana.albu@emi.utm.md
}

How to cite this paper: Albu, S. and Albu, I. (2021) Depreciation of the Economic Value of Historic Properties. Open Journal of Applied Sciences, 11, 1256-1267. https://doi.org/10.4236/ojapps.2021.1111095

Received: October 10, 2021

Accepted: November 27, 2021

Published: November 30, 2021

Copyright (c) 2021 by author(s) and Scientific Research Publishing Inc. This work is licensed under the Creative Commons Attribution International License (CC BY 4.0).

http://creativecommons.org/licenses/by/4.0/

\begin{abstract}
Historic properties are cultural, historic and/or architectural heritage assets that may have legal or statutory protection due to their cultural and economic importance. Often the real estate with a certain historical value is privately owned, and the owners request the estimation of the value of these properties, either for advisory purposes, or to gage the property for the purpose of lending, or for other purposes. In this research, the authors, within the framework of the cost approach, analyze the peculiarities of estimating the depreciation of the economic value of real estate properties with historic/architectural value. The emphasis is placed on the methods of estimating the physical depreciation and it is recommended to apply them depending on the condition of the construction and the use or non-use of the real estate for a long time. Based on a case study, the authors explain the paradox of the value of real estate with advanced age located in compact historical areas.
\end{abstract}

\section{Keywords}

Real Estate, Valuation, Cost Approach, Physical Wear, Functional Depreciation, Economic Depreciation

\section{Introduction}

From the point of view of economic evaluation [1], historic properties are the assets of cultural, historical and/or architectural heritage that may have legal or statutory protection due to their cultural and economic importance. A historic property is a real estate publicly recognized or officially designated by a government commission as having historical or cultural importance because of its association with a historical event or historical period, architectural style, or national heritage. These properties are commonly associated with four characteristics: 1 ) their historical, architectural and/or cultural importance; 2) the statutory or legal 
protection they can enjoy; 3 ) constraints and limitations on the use, transformation and transfer; and 4) the frequent obligation in some jurisdictions to be accessible to the public.

Through historic property, we assume several categories of real estate. Some historic properties have been restored to their original condition; some have been partially restored (e.g. the façade of the building); and others have not been restored at all. Historic properties also include properties partially adapted to current standards (e.g. space within them), as well as properties that have been extensively upgraded. All historic properties have a historical character of a certain degree.

The value of real estate, according to the widely accepted global practice, is estimated by three approaches, from three points of view on value: the market approach, the income approach and the cost approach. Historic properties may also be assessed by the methods within those approaches provided that special aspects are considered to be conditioned by the nature of the methods and materials of the old constructions; the efficiency and current performance of such properties, in terms of equivalent modern assets; the adequacy of the methods used to repair/restore or restore/rehabilitate the properties, as well as with the character and scope of the legal or statutory protections they enjoy; the adequacy of the methods used to repair/restore or restore/rehabilitate the properties, as well as with the character and scope of the legal or statutory protections they enjoy.

According to our previous research [2] [3], the real value of the architectural heritage will be determined: 1) by the method of updating the cash flows, if there is sufficient information for its application; or 2) by determining the sum of the economic value of the immovable property and its cultural/architectural value (Figure 1).

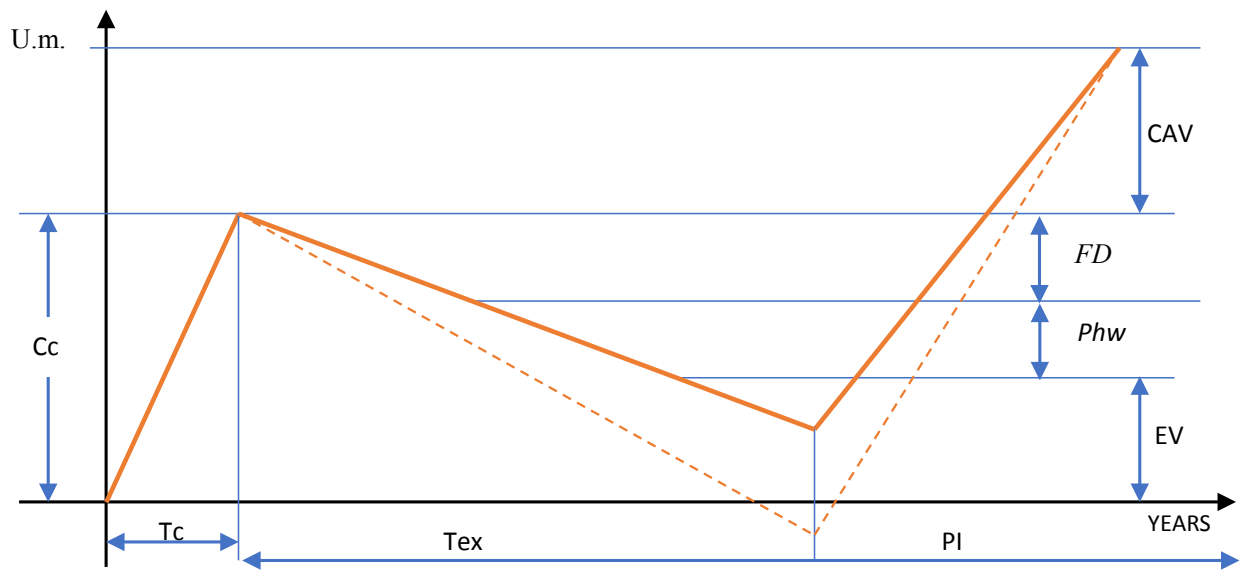

Figure 1. The structure of the value of the building considered as historic property (Tcconstruction period; Tex-exploitation period; PI-period of exploitation as a historic property; $\mathrm{Cc}$-the initial construction cost of the building (reconstitution cost/replacement cost); EV-the economic value of the building; Phw-physical wear; FD—functional depreciation; CAVcultural/architectural value.). 
The economic value of the immovable property will be determined in accordance with the potential use of the objective (market or investment value), using the methods of the income approach. The cost approach will be used only if the object does not generate revenue (the net operating income is null or negative). The evaluation will be carried out according to the modern evaluation methodology without taking into account the existence of cultural/architectural value.

The application of the cost approach methods is often required on emerging markets, when the historical heritage is not yet included in the economic circuit or if the legislation provides for the application of methods within all three approaches to evaluation (as in the case of the Republic of Moldova).

The International Valuation Standards (IVS) ([1], section 5.2.3) on the cost approach contain only the following provisions: when applying the cost approach to the valuation of historical properties, the valuer must assess whether the characteristics/appearance of the building will have an intrinsic value on the market of that property. In other words, the service potential of such buildings is inseparable from its historic characteristics. The modern equivalent of these properties will have to reflect either the cost of breeding a replica or, if this is not possible due to the non-existence of original materials or techniques, the cost of a modern building of similar specificity...

In all cases, the corrections made to reflect the physical deterioration and functional depreciation will have to reflect factors such as the high cost of maintaining the historic property, as well as the loss of flexibility to adapt the building to the changed needs of an occupant...

How the size of the physical deterioration and functional depreciation will be estimated (Figure 1) in the process of estimating the value of historic properties remains at the discretion of the valuer.

In this article, the authors analyze the applicability of methods for estimating the depreciation of the economic value of historical properties. In particular, the reduction of value due to accumulated physical wear and tear and functional obsolescence existing at the valuation date is examined. The authors examine the advantages and disadvantages of the methods recommended in building codes and the literature for calculating physical wear and tear for buildings with architectural value. Some particular aspects of applying the examined methods in the case of real estate with architectural/historical value are recommended.

Based on a case study, the paradox of the depreciation of the value of real estate located in compact historical areas is exemplified-the real estate has a market value while the net replacement cost (considering physical wear and tear and functional depreciation) is negative.

\section{Depreciation of the Value of Immovable Property (Obsolescence)}

According to THE SIE ([4], p. 1), "the cost approach provides an indication of the value by calculating the current replacement cost of an asset and making reductions for physical deterioration and all other relevant forms of depreciation". 
Depreciation is of three types: physical depreciation, functional depreciation (Functional Obsolescence) and economic/external depreciation (Economic Obsolescence). For historic properties, only the first two types of depreciations are characteristic.

According to international professional standards, physical depreciation "is any loss of utility caused by physical damage to the asset or its components as a result of its age and normal wear and tear, which is materialized in a loss of value" ([4], p. 12). And, "functional depreciation is any loss of utility caused by deficiencies in the subject asset, compared to its substitute, which leads to a loss of value" ([4], p. 14).

In the specialized literature we encounter synonymous notions: physical depreciation and physical wear and tear.

According to the act, regulating the method of valuation of real estate in the Republic of Moldova [5] "Physical wear represents a reduction of the value of the immovable property that is due to its deterioration under the influence of the time factor and other external factors (physical, chemical factors, incorrect exploitation of the building, unsatisfactory maintenance of the construction, etc.)".

From a technical point of view, wear and tear represent degradation, damage to an element of the construction ([6], p. 215). Physical wear is the loss of initial technical and operational qualities (strength, stability, reliability...) as a result of the influence of environmental factors, climatic factors and human activity ([7], p. 32). Physical wear and tear in construction elements, systems and a complete building is manifested by the appearance and development of defects and damage at the time of its assessment. The causes that contribute to the aging of a building are diverse: the deprecation of materials, structures, the negative impact of the external environment or human activities. The development of physical wear and tear is influenced by factors such as the type of building structure, population density, the level of maintenance of the building, the volume and nature of capital repairs, the quality of repair work, sanitary and hygienic factors: insolation, aeration, periods of operation, the level of maintenance and current repairs.

The consequences of physical damage to the building lead to the reduction or loss of useful capacities, among which we will note: the deterioration of thermal and sound insulation, ventilation systems, violation of indoor air circulation, increased humidity in the building, etc.

Functional depreciation takes two forms: 1) an overspending, which may be caused by the changes in the project, building materials, technology or manufacturing techniques, changes that result in the availability of modern equivalent assets with lower capital expenditures than those of the underlying asset; 2) over-operating expenses, which may be caused by project improvements or over capacity, resulting in the existence of modern equivalent assets with lower operating costs than those of the underlying asset ([4], p. 14).

The evaluators [11] express the functional depreciation through the lack, excess or moral wear of the useful qualities, of exploitation of buildings and con- 
structions, such as:

- The corresponding size of the building's destination (constructive scheme, volume, area, height, etc.);

- Availability of facilities (ensuring the technical-sanitary environment, engineering systems, etc.);

- Reliability in operation (strength, rigidity, stability, durability, fire safety, fire resistance, thermal protection, waterproofness, etc.);

- Ecology of the object of assessment (internal and external ecological cleaning of the object, existence of modern exploitation technology that allows the control and compliance with the requirements for environmental pollution);

- The exterior in accordance with the modern architectural, ergonomic and aesthetic requirements;

- Efficiency of territorial development.

Builders [12] express functional depreciation through "obsolescence" (malfunctions of the constructional scheme, lack of engineering networks, mismatch with current normative requirements in constructions) calculated as a percentage of the reconstitution value of the building.

The specialty literature [1] [4] [5] [7] [8] [9] [10] [11], for estimating depreciation, recommends the application of different methods that differ depending on the possibility of recovering the lost value. The literature of the Russian Federation differentiates the functional depreciation on three types, by modifying the methods proposed by the Appraisal Institute (USA). The synthesis of methods is proposed in Table 1.

As we can see from the table, the physical wear and tear (physical depreciation) of buildings is unanimously recommended to determine, based on the lifetime of the structure (the effective age method) and its real condition (value method - postponed repair).

Table 1. Recommended methods for estimating the physical and functional impairment of the value.

\begin{tabular}{|c|c|c|c|}
\hline Depreciation & USA & Russia & Republic of Moldova \\
\hline \multicolumn{4}{|c|}{ PHYSICAL WEAR AND TEAR } \\
\hline Recoverable wear & $\begin{array}{l}\text { Postponed repair } \\
\text { To postpone } \\
\text { The cost of repair works }\end{array}$ & The cost of repair works & $\begin{array}{l}\text { The value method } \\
\text { The effective age method }\end{array}$ \\
\hline $\begin{array}{l}\text { Unrecoverable } \\
\text { wear }\end{array}$ & The effective age method & $\begin{array}{l}\text { The effective age method } \\
\text { The regulatory method } \\
\text { The expert method }\end{array}$ & $\begin{array}{l}\text { The regulatory method (including the } \\
\text { expert method) }\end{array}$ \\
\hline \multicolumn{4}{|c|}{ FUNCTIONAL DEPRECIATION } \\
\hline $\begin{array}{l}\text { Recoverable } \\
\text { depreciation }\end{array}$ & $\begin{array}{l}\text { Summing the costs necessary for } \\
\text { removal }\end{array}$ & $\begin{array}{l}\text { Summing the costs necessary for } \\
\text { removal }\end{array}$ & Summing the costs necessary for removal \\
\hline $\begin{array}{l}\text { Unrecoverable } \\
\text { depreciation }\end{array}$ & $\begin{array}{l}\text { Capitalization of rent losses } \\
\text { Capitalization of excessive } \\
\text { expenditure }\end{array}$ & $\begin{array}{l}\text { The modified method of } \\
\text { capitalization of losses } \\
\text { (or excessive costs) }\end{array}$ & $\begin{array}{l}\text { Method of capitalization of losses of rent } \\
\text { payment } \\
\text { Method of capitalization of regulatory } \\
\text { surplus losses }\end{array}$ \\
\hline
\end{tabular}




\section{Applicability of Methods for Calculating the Depreciation of Value to Historical Properties}

The depreciation of the economic value of a historical property depends primarily on the degree of its physical deterioration and functional mismatch.

The damage to a historic building is of two types: repairable and irreparable. In the first case, the damage to the building occurs gradually, it can be slowed down by taking appropriate and timely measures. In the second case, no measures will help, since such a structure is subject to demolition or total replacement.

Analogously, from an economic point of view, the depreciation of the value is recoverable and irrecoverable. Recoverable depreciation is the one whose demolition is physically possible and economically efficient. Recoverable depreciation includes expenses related to the removal of the elements of depreciation as a result of which the value of the immovable property valued will increase. The irrecoverable depreciation is the depreciation, the expenses for the removal of which will be higher than the probable increase in the value of the immovable property following the removal of the elements of depreciation.

Referring to historic properties, that statement has exceptions. Thus, we can meet with historic properties where the cost of removing the reparable damage does not increase the economic value of the immovable property, but retains or increases the cultural/historic value, which was analysed by the authors previously [2] [3].

Therefore, the reparable deterioration of historical properties in some cases economically unrecoverable is culturally recoverable.

We will examine the methods indicated in Table 1 from the point of view of their applicability for buildings with historical value. In detail, the methods for calculating physical wear from the point of view of technical valuation are set out by the authors in the paper "Technical valuation of buildings" [13].

The effective age method involves the calculation of physical wear and tear by relating the actual (chronological) age to the physical (normative) life span.

It is a simple method and it is based on a single arithmetic operation. The size of the physical life span is taken from the normative documents for the operation of buildings and does not require a special justification.

Referring to historic buildings, the application of the effective age method is not possible because the actual age exceeds the normative duration of operation of the building.

The national regulations [5] propose another version of that method:

$$
\mathrm{PhW}=\mathrm{AT} /(\mathrm{AT}+\mathrm{RPhL})
$$

In which: $\mathrm{PhW}$ - physical wear, $\mathrm{AT}$-actual age (time), $\mathrm{RPhL}$ - the remaining physical life.

The method could be applied in this form, but determining the size of the remaining physical life involves additional analyses and calculations. These calculations will focus on the appreciation of the physical characteristics of the con- 
structive elements such as durability, permeability, load-bearing capacity, etc. The control and assessment of the physical deterioration of the constructive elements can be carried out by destructive and non-destructive methods. Nondestructive testing does not involve opening, scraping building structures to assess their condition and it is preferable in the case of estimating the economic value. Following the technical expertise of the constructive elements, the assessor can determine the remaining physical life and respectively the physical life of the building in full.

The value method/the method of the postponed repair involves the estimation of the physical depreciation by determining the cost of the necessary repair works. This method allows an excellent substantiation of the economic essence of the size of physical wear.

In the case of the valuation of historic real estate, we notice several disadvantages in the process of applying the value method:

1) Mandatory detailing and accuracy of the calculation of costs for the execution of repair works of the worn elements of the building. An additional justification of the need and the existence of permission to repair/renovate/modernize or replace a particular element is required.

2) The complexity of practical implementation:

a) it is difficult to elaborate the specifications, because in the process of rehabilitation of historical constructions, as a rule, there is a need to carry out additional, unforeseen works;

b) it is complicated to accurately determine the physical volume of repairs for each element;

c) it is difficult to choose a suitable cost norm.

Therefore, the application of the valuation method to historical properties provides the highest data with the highest accuracy, but it is also the most expensive due to the high workload.

In case of impossibility to apply the method of effective age for construction (impossibility of carrying out the technical expertise) and the value method (because it considerably increases the cost of valuation services) the normative method or a mixed variant of the named methods can be applied.

The regulatory method involves determining the size of the physical wear based on the analysis of the technical condition of the basic construction elements of the building. This method is applied in two steps [5]:

1) The physical wear and tear of each construction element is determined;

2) The physical wear and tear of the integral construction is determined.

A) Depending on the method of performing the first stage, the name of the method varies: the expert method or the regulatory method.

The expert method is called the method focused on the specialist's opinion on the physical wear of the constructive element assessed on the basis of the defects observed in the process of building inspection ([9], p. 134).

The application of this method is relatively easy, as it involves simple calculations and requires a reduced amount of time from the assessor's part. The 
methodology for determining the physical wear and tear shall be regulated at country level and described in sufficient details. The evidentiary part is evident, especially when the opinions of several assessors reflected in the technical assessment reports of the construction converge and correspond completely.

At the same time, the expert method has several disadvantages:

1) The technique itself ensures a calculation accuracy of $\pm 5 \%$. The physical wear and tear for a particular item considered as "Good" can be determined, in $25 \%$ or $30 \%$. The $5 \%$ difference leads to an often-inexplicable subjectivity.

2) The size of the error is inversely proportional to the experience of the assessor. In addition, quite common are situations when a simple cosmetic repair hides many visible signs of wear of the main structural elements of the building, which leads to a significant underestimation of the physical depreciation of the value of the building as a whole.

3) The norms to which we refer [14] do not contain the detailed description of the damages that can be detected, and the evaluator's decisions are subjective and depend on the knowledge and practical experience in the field of constructions.

4) The methodology shall not take into account the difference in unit prices for new construction and repair works. We mention that for historical buildings the cost of construction works differs from 1.05 to 1.45 , depending on the condition.

The regulatory method is called the method focused on the estimation of physical wear according to the norm "Rules for estimating physical wear" [15], analogous in Belorussia [16]. Within it there are two variants of estimating the wear of the constructive element: according to the chronological age and according to the technical condition.

For constructions whose chronological lifetime span exceeds the normative service life, to which historical properties also refer, physical wear and tear is recommended to be determined by the second formula [17]. But most practitioners prefer the analysis of the technical condition because to argue the remaining physical life span is quite complicated.

B) During the second stage, the physical wear and tear of the building is determined in full as the sum of the weighted values of the physical wear and tear of the separated elements. The rate of the reconstitution value of the constructive element in the reconstitution value of the building is considered as a weight. The rates are considered according to the norm "Compendium of the combined indices of the reconstitution value" [18] or according to the Regulation on the issuance of the technical approval certifying the degree of execution of the construction and the compliance of the construction works with the project documentation [19].

\section{Depreciation of Value-The Paradox of Historical Areas (Case Study)}

The historical center of Chisinau is the central area of the capital of the Republic of 
Moldova, which concentrates about 1000 buildings of local and national historical importance, erected in the large part in the interval: the second half of the XIX century - the first half of the twentieth century, arranged according to the principle of closed neighbourhoods, old churches, architectural monuments, etc.

The historical center is located within the limits of the administrative territory of the sectors Buiucani, Centru and Râșcani and is located on the perimeter of the streets: A. Mateevici - C. Stere - St. Andrei - I. Zaikin - Albișoara - Ismail Stefan cel Mare şi Sfânt - Ciuflea - Bucharest - L. Tolstoi - Ismail, with a total area of 619 ha.

In the Historical Center there are many real estates with a separate ownership right: the right to the land belongs to the local or central public administration, and the right to the construction belongs to one or a few natural (or legal) persons. In the case of the valuation of such immovable property, the full right to the construction and only the fractional right of use over the land that is in common use of the neighbours must be considered.

The object of the evaluation represents a part ( 35.9 s.m.) of the building built in 1918 with a total area on the interior perimeter of 289 s.m. The reconstitution value of the apartment with a room, kitchen, sanitary knot and entrée is 23,500 euros.

Determined physical depreciation: by the expert method is $35 \%$; by the regulatory method based on chronological age is $57 \%$.

The functional depreciation was determined by capitalizing on the rent losses. There were analysed the rent offers of the analog apartments located in the Historical Center in old buildings (the end of the 19th century - the beginning of the 20th century) and new buildings ( 21 century). As a result of the calculations, the functional depreciation constitutes about 20,600 euros or $88 \%$ of the reconstitution value of the object of evaluation.

Therefore, the value of the object of the assessment considering the physical wear and tear and the functional depreciation is negative. However, the analysis of the market indicates that the apartments located in the old buildings in the Historical Center are offered on the market with 673 euros/s.m. - 1100 euros/s.m. depending on the physical condition of the building and the type of internal repair of the apartment.

A comparative analysis of the rent for the one-room apartments in the new buildings located in the Historical Center and its periphery in the Center administrative sector was carried out. There was an average monthly difference of 322 euros. The economic depreciation (in this case the increase in value) determined by the method of capitalization of the surplus of income due to the placement in the Historical Center of the object of the valuation constitutes about 31,000 euros. For advisory purposes, the value of the full right to the land has been estimated (the share that belongs to the object of the valuation). Following the calculations, we find that the value of the land considered free is lower than the "economic depreciation" of the object of the valuation about $82 \%$.

Thus, the value of the apartment estimated by the cost approach falls within the tolerance range allowed for the evaluation results. 


\section{Discussion}

The cost approach is often not applied by practising appraisers in valuing ageing property, with the argument that the chronological age has exceeded the normative life span, i.e. the expense method does not give an accurate indication of value. It is claimed that the results obtained by the different approaches do not fall within the acceptable tolerance range and it is sufficient to apply the market approach.

In this research we have demonstrated the possibility of using the cost approach, the necessity and the way of considering the particularities of the real estate in the valuation process.

The correct application of the cost approach is necessary in various practical situations. It becomes paramount in the event of legal disputes (e.g. breach of building regulations on neighbouring land impacting on the subject of valuation).

\section{Conclusions}

The analysis carried out has led to the following conclusions:

1) The methods of the cost approach can be applied in the case of historical properties only taking into account the legislative particularities, prohibitions and potential usefulness characteristic of the specific object.

2) The reparable deterioration of historical properties in some cases economically un-recoverable is culturally recoverable.

3) In order to determine the physical depreciation of the historic properties in operation, we recommend the application of the regulatory method with the involvement of the opinion of the construction expert.

4) In order to determine the physical depreciation of historical buildings, which were not used for a long time, we recommend applying the method of effective age with the estimation of the remaining physical lifetime span by the non-destructive methods.

5) For the buildings located in the compact historical areas with a considerable lifetime span, but not considered a historic/architectural patrimony, the paradox of value is found: summarily the physical and functional depreciation exceeds the reconstitution value of the immovable property. The economic value of the property is created by the recognition of the site as an area of historic value

\section{Acknowledgements}

The research was carried out within the project 20.80009.0807.34 increasing the value of architectural heritage of R. Moldova.

\section{Conflicts of Interest}

The authors declare no conflicts of interest regarding the publication of this paper. 


\section{References}

[1] International Valuation Standards Committee (2007) Standardele Internaţionale de Evaluare Ediția a opta 2007.

[2] Albu, S., Albu, I., Ursu, V., et al. (2020) Patrimoniul arhitectural: Aspecte legale, tehnice și economice. Universitatea Tehnică a Moldovei, Chișinău.

[3] Albu, S. (2021) The Economic Value and Valuation of Architectural Heritage. Journal of Building Construction and Planning Research, 9, 1-11. https://doi.org/10.4236/jbcpr.2021.91001

[4] International Valuation Standards Council (2012) Îndrumar pentru evaluare. Vol. 2: Abordarea prin cost pentru activele corporale. IROVAL, București.

[5] Hotărîrea Guvernului (2003) Despre aprobarea Regulamentului provizoriu privind evaluarea bunurilor imobile. Monitorul Oficial Nr. 177. http://lex.justice.md/viewdoc.php?action=view\&view=doc\&id=305725\&lang=1

[6] Șchiopu, C. (2012) Construcții: Sisteme și subsisteme constructive. IROVAL, București.

[7] Bedov, A.I., Znamenskiy, V.V. and Gabitov, A.I. (2014) Assessment of the Technical Condition, Restoration and Strengthening of the Foundations and Building Structures of the Buildings and Structures in Use. Part 1. Assessment of the Technical Condition of the Foundations and Building Structures of the Buildings and Structures in Use. ASV Publishing, Lymington.

[8] Appraisal Institute (2007) The Appraisal of Real Estate. 11th Edition, Appraisal Institute.

[9] Kosorukova, I.V., et al. (2009) Appraisal Activity. Assessment of the Value of the Property. DS Market.

[10] Gribovsky, S.V. (2009) Real Estate Appraisal. Maroseyka, Moscow.

[11] Aleksandrov, V.T. (2010) Assessment of Obsolescence and Best Use of Real Estate. Stroyinformizdat, Moscow.

[12] Wolfson, V.L. Ilyashenko, V.A. and Komisarchik, R.G. (1996) Reconstruction and Overhaul. Stroyizdat, Moscow. https://sng1lib.org/book/3084382/b62393?id=3084382\&secret=b62393

[13] Albu, I. and ASlbu, S. (2020) Evaluareatehnică a construcțiilor: Curs de prelegeri. Universitatea Tehnică a Moldovei, Chișinău.

[14] Decision of the Soviet of Ministers of the Republic of Moldova. (1982) Norms for the Evaluation of Constructions Belonging to the Citizens of the Republic of Moldiva for the Purpose of State Insurance. No. 119 of March 29.

[15] Departmental Building Codes (1987) Rules for Assessing the Physical Deterioration of Residential Buildings. Gosgrazhdanstroy, Moscow.

http://www.ocenchik.ru/docs/3.html

[16] Technical Code TKP 45-1.04-119-2008 (02250) Assessment of the Degree of Physical Wear and Tear. Ministry of Architecture and Construction of the Republic of Belarus Minsk 2009. http://www.amac.md/Biblioteca/data/29/02/02/06/45.2.pdf

[17] Mikhalevich, N.V. (2006) Technical Maintenance of Buildings and Structures. VOSTU, Vologda. https://studfile.net/preview/4215565/

[18] Collections of Enlarged Indicators of the Replacement Value of Buildings and Structures. https://upvs-online.ru/

[19] Ministerul Dezvoltării Regionaleși Construcțiilor (2011) Cu privire la aprobarea Regulamentului privind emiterea avizului tehnicce atestă gradul deexecutare a 
construcției şi corespunderea lucrărilorde construcție cu documentaţia de proiect. Monitorul Oficial Nr. 128-130 art. 1057.

https://www.legis.md/cautare/getResults?doc id=63890\&lang=ro 